\title{
Inhibitory Effect of Aqueous Extract of Stem Bark of Cissus populnea on Ferrous Sulphate- and Sodium Nitroprusside-Induced Oxidative Stress in Rat's Testes In Vitro
}

\author{
Seun F. Akomolafe, ${ }^{1,2}$ Ganiyu Oboh, ${ }^{2}$ Afolabi A. Akindahunsi, \\ Ayodele J. Akinyemi, ${ }^{2,3}$ and Oluwatosin G. Tade ${ }^{1}$ \\ ${ }^{1}$ Department of Biochemistry, Ekiti State University, PMB 5363, Ado-Ekiti, Nigeria \\ ${ }^{2}$ Department of Biochemistry, Federal University of Technology, PMB 704, Akure, Nigeria \\ ${ }^{3}$ Department of Biochemistry, Afe Babalola University, PMB 5454, Ado-Ekiti, Nigeria
}

Correspondence should be addressed to Seun F. Akomolafe; purposefulseun@yahoo.co.uk

Received 14 November 2012; Accepted 13 December 2012

Academic Editors: R. J. Beninger, S. Cuzzocrea, J.-R. Sheu, and T. W. Stone

Copyright (C) 2013 Seun F. Akomolafe et al. This is an open access article distributed under the Creative Commons Attribution License, which permits unrestricted use, distribution, and reproduction in any medium, provided the original work is properly cited.

\begin{abstract}
Cissus populnea are plants associated with a myriad of medicinal uses in different parts of the world and are good sources of carotenoids, triterpenoids, and ascorbic acid. The antioxidant properties and inhibitory effect of water extractible phytochemicals from stem bark of C. populnea on $\mathrm{FeSO}_{4}$ and sodium nitroprusside- (SNP-) induced lipid peroxidation in rat testes were investigated in vitro. The results revealed that the extract was able to scavenge DPPH radical, chelate $\mathrm{Fe}^{2+}$ and also had a high reducing power. Furthermore, the incubation of the testes tissue homogenate in the presence of $\mathrm{FeSO}_{4}$ and $\mathrm{SNP}$, respectively, caused a significant increase in the malondialdehyde (MDA) contents of the testes. However, the aqueous extract of the stem bark of $C$. populnea caused a significant decrease in the MDA contents of both Fe ${ }^{2+}\left(\mathrm{EC}_{50}=0.027 \mathrm{mg} / \mathrm{mL}\right)$ and SNP- $\left(\mathrm{EC}_{50}=0.22 \mathrm{mg} / \mathrm{mL}\right)$ induced lipid peroxidation in the rat testes homogenates in a dose-dependent manner. The water extractible phytochemicals from C. populnea protect the testes from oxidative stress and this could be attributed to their high antioxidant activity: DPPH-scavenging ability, $\mathrm{Fe}^{2+}$-chelating and -reducing power. Therefore, oxidatively stress in testes could be potentially managed/prevented by this plant.
\end{abstract}

\section{Introduction}

Infertility is a major clinical problem, affecting people medically and psychosocially. In recent years, oxidative stress has been implicated in the progression of male infertility. Evidence has shown that these damaging events are caused by free radicals [1]. Oxidative stress results from either a decrease of natural cell antioxidant capacity or an increased amount of reactive oxygen species (ROS) in organisms. However, the consumption of foods rich in antioxidant phytochemicals may help fight degenerative diseases caused by oxidative stress by improving body's antioxidant status.

High levels of Fe play a crucial role in degenerative diseases by acting catalytically in the production of ROS which have the potential to damage cellular lipids, nucleic acids, proteins, and carbohydrate resulting in wide-ranging impairment in cellular function and integrity [2]. ROS can directly attack the polyunsaturated fatty acids of the cell membranes and induce lipid peroxidation. Malondialdehyde (MDA) is the end-product of lipid peroxidation, which is a process where reactive oxygen species (ROS) degrade polyunsaturated fatty acids.

Recently, much attention has been focused on the role of the antioxidative defense system to combat oxidative stress [3]. Endogenous antioxidants in plants may play an important role in antioxidative defense against oxidative damage [4], possibly preserving the biological functions of cells [5]. There is an increasing interest in the protective biological function of natural antioxidants contained in dietary plants, which are candidates for the prevention of oxidative damage [6]. These antioxidants are polyphenolic compounds, which are found in all plants and in all parts of 
the plants (tree bark, stalks, leaves, fruits, roots, flowers, pods, and seeds) [6].

Cissus populnea is a plant associated with a myriad of medicinal uses in different parts of the world. Its extracts have been credited with antibacterial properties [7], as an antitrypanosomal plant and a source of gum powder [8] and as a component of a herbal antisickling Nigerian formula [9]. In Benin Republic, it is used for its diuretic properties while in Ghana it is used as a postharvest ethnobotanical protectant [10]. The aqueous extract of its stem bark is associated with aphrodisiac/fertility potentials among the Yoruba-speaking people of South West Nigeria [11]. The use of C. populnea, as an aphrodisiac and fertility enhancer amongst the males, has been attributed to the declining fertility trend that has been established in this population over the years coupled with the attendant increasing levels of erectile dysfunction [12]. Although C. populnea has been reportedly used in traditional medicine for the management/prevention of infertility diseases associated with oxidative stress, there is still limited information on some of the possible mechanisms by which they exert this effect. Hence, the objective of this study is to investigate the inhibitory effect of water extractible phytochemicals from stem bark of C. populnea on $\mathrm{Fe}^{2+}$ and SNP-induced lipid peroxidation in rat's testes in vitro.

\section{Materials and Methods}

2.1. Sample Collection. Fresh samples of stem bark of Cissus populnea were purchased in a local market, in Akure metropolis, Nigeria. Authentication of the plant was carried out in the Department of Biology, Federal University of Technology, Akure, Nigeria.

2.2. Chemicals and Reagents. Chemicals and reagents used such as thiobarbituric acid (TBA), 1,10-phenanthroline, deoxyribose, gallic acid, and Folin-Ciocalteau's reagent were procured from Sigma-Aldrich, Inc., (St. Louis, MO, USA), trichloroacetic acid (TCA) was sourced from Sigma-Aldrich, Chemie GmbH (Steinheim, Germany), dinitrophenyl hydrazine (DNPH) from ACROS Organics (NJ, USA), hydrogen peroxide, methanol, acetic acid, and $\mathrm{FeCl}_{3}$ were sourced from $\mathrm{BDH}$ Chemicals Ltd., (Poole, England), thiourea, $\mathrm{CuSO}_{4} \cdot 5 \mathrm{H}_{2} \mathrm{O}, \mathrm{H}_{2} \mathrm{SO}_{4}$, sodium carbonate, $\mathrm{AlCl}_{3}$, potassium acetate, Tris-HCl buffer, sodium dodecyl sulphate, $\mathrm{FeSO}_{4}$, and potassium ferricyanide were of analytical grade while the water was glass distilled.

2.3. Aqueous Extract Preparation. The sample was washed under running water, air dried after which the dried sample was grinded to powdered form, and kept dry in an air-tight container prior to the extraction. $1 \mathrm{~g}$ of the powdered sample was weighed into $20 \mathrm{~mL}$ of distilled water and was left for 24 hours [13]. The mixture after 24 hours was filtered and the filtrate centrifuged at $805 \times \mathrm{g}$ for 10 minutes. The clear supernatant collected and was used for subsequent analysis.

2.4. Determination of Total Phenolic Content. The total phenolic content was determined using the method reported by Singleton et al. [14]. Appropriate dilutions of the extract were oxidized with $2.5 \mathrm{~mL}$ of $10 \%$ Folin-Ciocalteau's reagent $(\mathrm{v} / \mathrm{v})$ and neutralized by $2.0 \mathrm{~mL}$ of $7.5 \%$ sodium carbonate. The reaction mixture was incubated for 40 minutes at $45^{\circ} \mathrm{C}$, and the absorbance was measured at $765 \mathrm{~nm}$ in the spectrophotometer (JENWAY 6305, Barloworld Scientific, Dunmow, UK). The total phenolic content was subsequently calculated and expressed as mg gallic acid equivalent/g dry weight.

2.5. Determination of Total Flavonoid Content. The total flavonoid content of the sample was determined using a slightly modified method reported by Meda et al. [15]. Briefly $0.5 \mathrm{~mL}$ of appropriately diluted sample was mixed with $0.5 \mathrm{~mL}$ methanol, $50 \mu \mathrm{L} 10 \% \mathrm{AlCl}_{3}, 50 \mu \mathrm{L} 1 \mathrm{M}$ Potassium acetate, and $1.4 \mathrm{~mL}$ water, and allowed to incubate at room temperature for 30 minutes. The absorbance of the reaction mixture was subsequently measured at $415 \mathrm{~nm}$, and the total flavonoid content was subsequently calculated using quercetin as standard and expressed as $\mathrm{mg} / \mathrm{g}$ quercetin equivalent dry weight.

2.6. Determination of Vitamin C Content. Vitamin C content of the sample was determined using the method of Benderitter et al. [16]. Briefly, $75 \mu \mathrm{L}$ DNPH (2g dinitrophenyl hydrazine, $230 \mathrm{mg}$ thiourea, and $270 \mathrm{mg} \mathrm{CuSO}_{4} \cdot 5 \mathrm{H}_{2} \mathrm{O}$ in $100 \mathrm{~mL}$ of $5 \mathrm{M} \mathrm{H}_{2} \mathrm{SO}_{4}$ ) were added to $500 \mu \mathrm{L}$ reaction mixture (300 $\mu \mathrm{L}$ of an appropriate dilution of the extract with $100 \mu \mathrm{L}$ $13.3 \%$ trichloroacetic acid (TCA) and water). The reaction mixtures were subsequently incubated for $3 \mathrm{~h}$ at $37^{\circ} \mathrm{C}$, then $0.5 \mathrm{~mL}$ of $65 \% \mathrm{H}_{2} \mathrm{SO}_{4}(\mathrm{v} / \mathrm{v})$ was added to the medium; their absorbance was measured at $520 \mathrm{~nm}$ and the vitamin C content of the sample was subsequently calculated using ascorbic acid as standard and expressed as $\mathrm{mg} / \mathrm{g}$ ascorbic acid equivalent.

\subsection{Lipid Peroxidation Assay}

2.7.1. Experimental Animals. Ten male wistar albino rats weighing between 190 and $250 \mathrm{~g}$ were purchased from the Central Animal House, Department of Biochemistry, University of Ilorin, Ilorin, Nigeria. They were housed in stainless steel cages under controlled conditions of a $12 \mathrm{hr}$ light/dark cycle, $50 \%$ humidity, and $28^{\circ} \mathrm{C}$ temperature. The rats were allowed to assess food and water ad libitum. The animals were used in accordance with the procedure approved by the Animal Ethics Committee of the Federal University of Technology, Akure, Nigeria.

2.7.2. Preparation of Tissue Homogenates. The rats were decapitated under mild diethyl ether anaesthesia, and the testes (tissue) were rapidly dissected and placed on ice and weighed. This tissue was subsequently homogenized in cold saline $(1 / 10 \mathrm{w} / \mathrm{v})$ with about 10 -up- and downstrokes at approximately $1200 \mathrm{rev} / \mathrm{min}$ in a Teflon glass homogenizer (Mexxcare, mc14 362, Aayushi Design Pvt. Ltd. India). The homogenate was centrifuged (KX3400C Kenxin Intl. Co., Hong Kong) for 10 minutes at $3000 \times \mathrm{g}$ to yield a pellet that 
was discarded and a low-speed supernatant (SI), which was kept for lipid peroxidation assay.

\subsubsection{Lipid Peroxidation and Thiobarbibutric Acid Reactions}

$\mathrm{Fe}^{2+}$-Induced Lipid Peroxidation. The lipid peroxidation assay was carried out using the modified method of Ohkawa et al. [17]. Briefly $100 \mu \mathrm{L}$ of the SI fraction was mixed with a reaction mixture containing $30 \mu \mathrm{L}$ of $0.1 \mathrm{M}$ pH 7.4 Tris$\mathrm{HCl}$ buffer, extract $(100 \mu \mathrm{L})$, and $30 \mu \mathrm{L}$ of $250 \mu \mathrm{M}$ freshly prepared $\mathrm{FeSO}_{4}$ as the prooxidant. The volume was made up to $300 \mu \mathrm{L}$ by water before incubation at $37^{\circ} \mathrm{C}$ for $2 \mathrm{hrs}$. The color reaction was developed by adding $300 \mu \mathrm{L} 8.1 \%$ SDS (sodium dodecyl sulphate) to the reaction mixture, this was subsequently followed by the addition of $500 \mu \mathrm{L}$ of acetic acid/HCl (pH 3.4) mixture and $500 \mu \mathrm{L}$ of $0.8 \%$ thiobarbituric acid (TBA). This mixture was incubated at $100^{\circ} \mathrm{C}$ for $1 \mathrm{hr}$. Thiobarbituric acid reactive species (TBARS) produced were measured at $532 \mathrm{~nm}$ and expressed as malondialdehyde (MDA) produced (\% control) using MDA standard curve (0$0.035 \mathrm{mM}$ ).

Also, for sodium nitroprusside- (SNP-) induced lipid peroxidation, the procedure was carried out as above using $5 \mathrm{mM}$ sodium nitroprusside (SNP) as the prooxidant.

2.7.4. DPPH-Free Radical Scavenging Ability. The free radical scavenging ability of the extracts against DPPH (1,1-diphenyl2 picrylhydrazyl) free radical was evaluated as described by Gyamfi et al. [18]. Briefly, an appropriate dilution of the extract $(1 \mathrm{~mL})$ was mixed with $1 \mathrm{~mL}$ of $0.4 \mathrm{mM}$ methanolic solution containing DPPH radicals, the mixture was left in the dark for $30 \mathrm{~min}$, and the absorbance was measured at $516 \mathrm{~nm}$. The control was carried out using $2 \mathrm{~mL}$ DPPH solution without the test samples. The percentage (\%) of DPPHfree radical scavenging ability was subsequently calculated as follows:

$$
\begin{aligned}
& \text { DPPH scavenging ability (\%) } \\
& \qquad=\left[\frac{(\text { AbsControl }- \text { AbsSamples })}{\text { AbsControl }}\right] \times 100 .
\end{aligned}
$$

2.7.5. $\mathrm{Fe}^{2+}$ Chelation Assay. The $\mathrm{Fe}^{2+}$ chelating ability of the extract was determined using a modified method of Minotti and Aust [19] with a slight modification by Puntel et al. [20]. Freshly prepared $500 \mu \mathrm{M} \mathrm{FeSO}_{4}(150 \mu \mathrm{L})$ was added to a reaction mixture containing $168 \mu \mathrm{L}$ of $0.1 \mathrm{M}$ Tris- $\mathrm{HCl}(\mathrm{pH}$ 7.4), $218 \mu \mathrm{L}$ saline and the extracts $(0-25 \mu \mathrm{L})$. The reaction mixture was incubated for $5 \mathrm{~min}$, before the addition of $13 \mu \mathrm{L}$ of $0.25 \% 1,10$-phenanthroline $(\mathrm{w} / \mathrm{v})$. The absorbance was subsequently measured at $510 \mathrm{~nm}$ in a spectrophotometer. The Fe (II) chelating ability was subsequently calculated with respect to the reference (which contains all the reagents without the test sample).

2.7.6. Determination of Reducing Property. The reducing property of the extract was determined by assessing the ability of the extract to reduce $\mathrm{FeCl}_{3}$ solution as described
TABLE 1: Total phenolic, flavonoid, and vitamin C content of stem bark of Cissus populnea (stem bark).

\begin{tabular}{lcc}
\hline $\begin{array}{l}\text { Phenolic content } \\
(\mathrm{mg} \mathrm{GAE} / \mathrm{g})\end{array}$ & $\begin{array}{c}\text { Flavonoid content } \\
(\mathrm{mg} \text { QUE/g) }\end{array}$ & $\begin{array}{c}\text { Vitamin C } \\
(\mathrm{mg} \mathrm{AAE} / \mathrm{g})\end{array}$ \\
\hline $17.33 \pm 0.00$ & $0.059 \pm 0.01$ & $22.06 \pm 0.37$ \\
\hline
\end{tabular}

Values represent means \pm standard deviation of triplicate readings.

GAE: gallic acid equivalent, QUE: quercetin equivalent, and AAE: ascorbic acid equivalent.

by Oyaizu [21]. A $2.5 \mathrm{~mL}$ aliquot was mixed with $2.5 \mathrm{~mL}$ of $200 \mathrm{mM}$ sodium phosphate buffer ( $\mathrm{pH} 6.6$ ) and $2.5 \mathrm{~mL}$ of $1 \%$ potassium ferricyanide. The mixture was incubated at $50^{\circ} \mathrm{C}$ for $20 \mathrm{~min}$, and then $2.5 \mathrm{~mL}$ of $10 \%$ trichloroacetic acid was added. This mixture was centrifuged at $650 \mathrm{rpm}$ for $10 \mathrm{~min}$. $5 \mathrm{~mL}$ of the supernatant was mixed with an equal volume of water and $1 \mathrm{~mL}$ of $0.1 \%$ ferric chloride. The absorbance was measured at $700 \mathrm{~nm}$. The ferric reducing antioxidant property was subsequently calculated using ascorbic acid as standard.

2.7.7. Data Analysis. The results of the replicates were pooled and expressed as mean \pm standard deviation. Analysis of variance and Student's $t$-test were carried out [22]. Significance was accepted at $P \leq 0.05$.

\section{Results and Discussion}

Many plants are rich sources of phytochemicals, and intakes of these plant chemicals have protective potential against degenerative diseases [23]. The total phenolic content and total flavonoid content of stem bark of C. populnea are presented in Table 1. The total phenolic content of the plant $(17.33 \mathrm{mg} / \mathrm{g})$ is lower than what was reported for some hot peppers and green teas [24], but higher than some tropical leafy vegetables $[25,26]$. Phenolic compounds can protect the human body from free radicals, whose formation is associated with the normal metabolism of aerobic cells. They are strong antioxidants capable of removing free radicals, chelate metal catalysts, activate antioxidant enzymes, reduce alpha-tocopherol radicals, and inhibit oxidases [27].

The total flavonoid content of C. populnea $(0.059 \mathrm{mg} / \mathrm{g})$ is lower than what was reported for some tropical green leafy vegetables [28]. The presence of derivatives of flavonoids has been found in many herbs; moreover, numerous studies have conclusively shown that the majority of the antioxidant activity may be from compounds such as flavonoids, isoflavones, flavones, anthocyanins, catechin, and isocatechin rather than from vitamins $\mathrm{C}, \mathrm{E}$ and $\beta$-carotene $[29,30]$. Flavonoids have antioxidant activity and could therefore lower cellular oxidative stress [30]. Polyphenols are considered to be strong antioxidants due to the redox properties of their hydroxyl groups [31].

The vitamin $C$ content of stem bark of $C$. populnea is presented in Table 1. Vitamin $C$ has been reported to contribute to the antioxidant activities of plant food. Ascorbic acid is a good reducing agent and exhibits its antioxidant activities by electron donation $[25,26]$. It helps the immune system 


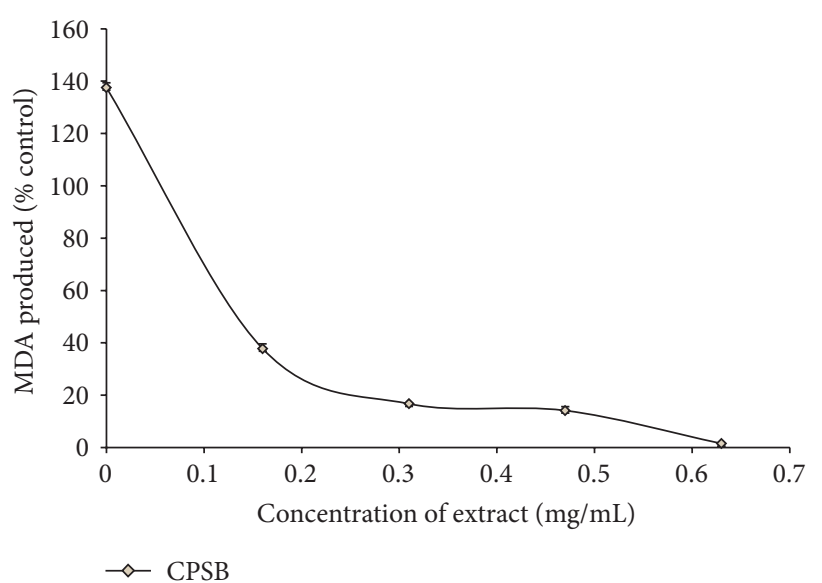

(a)

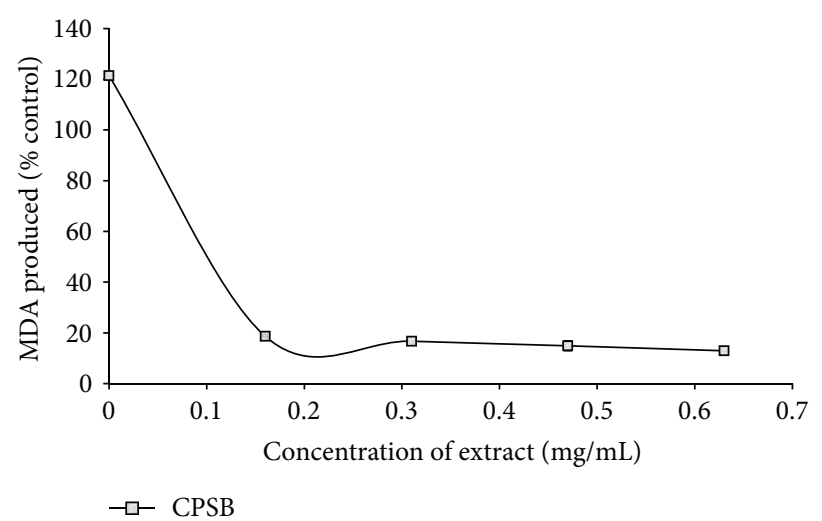

(b)

FIGURE 1: (a) Inhibition of $\mathrm{Fe}^{2+}$-induced lipid peroxidation in rat testis by aqueous extract of stem bark of Cissus populnea. (b) Inhibition of SNP-induced lipid peroxidation in rat testis by aqueous extract of stem bark of Cissus populnea.

to fight off foreign invaders and tumor cells and supports the cardiovascular system by facilitating fat metabolism and protecting tissues from free radical damage, and it assists the nervous system by converting certain amino acids into neurotransmitters. As a water-soluble antioxidant, vitamin $\mathrm{C}$ is in a unique position to "scavenge" aqueous peroxyl radicals before these destructive substances damage the lipids [32]. The vitamin C content of the plant is higher than that of related spices such as basil, bird pepper, black pepper, cinnamon, nutmeg, oregano, parsley and rosemary [33], and some commonly consumed green leafy vegetables in Nigeria $[25,26]$, green and red pepper, and some commonly consumed and underutilized tropical legumes [34]. It is also worth noting that the vitamin $\mathrm{C}$ content of the plant is higher than its total phenol content. The high vitamin $\mathrm{C}$ content of the plant will definitely contribute additively or synergistically to the observed antioxidant and medicinal properties of the plant.

Lipids are considered to be the most susceptible macromolecules and are present in male reproductive organ. One of the byproducts of lipid peroxidation is malondialdehyde, this byproduct has been used in various biochemical assays to monitor the degree of peroxidative damage sustained by spermatozoa [35, 36]. Testicular toxicity due to $\mathrm{Fe}^{2+}$ impairs fertility [37]. The finding that $\mathrm{Fe}^{2+}$ caused a significant increase in the MDA content of the testis homogenate agreed with earlier report where $\mathrm{Fe}^{2+}$ was shown to be a potent initiator of lipid peroxidation [14]. The increased lipid peroxidation in the presence of $\mathrm{Fe}^{2+}$ could be attributed to the fact that $\mathrm{Fe}^{2+}$ can catalyze one-electron transfer reactions that generate reactive oxygen species, such as the reactive $\mathrm{OH}^{\circ}$, which is formed from $\mathrm{H}_{2} \mathrm{O}_{2}$ through the Fenton reaction. Iron also decomposes lipid peroxides, thus generating peroxyl and alkoxyl radicals, which favors the propagation of lipid oxidation [38]. In the testis, Fe-induced lipid peroxidation destroys the structure of lipid matrix in the membranes of spermatozoa, and it is associated with loss of motility
TABLE 2: $\mathrm{EC}_{50}$ (extract concentration causing 50\% inhibition) values of Inhibition of $\mathrm{Fe}^{2+}$ - and SNP-induced lipid peroxidation in rat testis by aqueous extract of Cissus populnea (stem bark).

\begin{tabular}{lc}
\hline $\mathrm{EC}_{50}(\mathrm{mg} / \mathrm{mL}) \mathrm{Fe}^{2+}-$ & $\mathrm{EC}_{50}(\mathrm{mg} / \mathrm{mL}) \mathrm{SNP}-$ \\
induced lipid peroxidation & induced lipid peroxidation \\
\hline $0.027 \pm 0.01$ & $0.22 \pm 0.00$ \\
\hline
\end{tabular}

Values represent mean \pm standard deviation, number of samples $n=3$.

and impairment of spermatogenesis [37]. Therefore, possible depletion of iron could decrease oxidative stress throughout the whole body [39]. The ability of the water extractible phytochemicals from stem bark of $C$. populnea to inhibit $\mathrm{Fe}^{2+}$-induced lipid peroxidation in the testes homogenate is presented in Figure 1. The result revealed that the incubation of the testes homogenate in the presence of $\mathrm{Fe}^{2+}$ caused a significant $(P<0.05)$ increase in the MDA content $(137.5 \%)$ of the rat testes homogenate when compared with the basal (100\%). However, the aqueous extract of stem bark of $C$. populnea inhibited MDA production in rat's testes in a dosedependent manner $(0-0.63 \mathrm{mg} / \mathrm{ml})$. Nevertheless, judging by the $\mathrm{EC}_{50}$ (extract concentration causing $50 \%$ inhibition) values in Table 2 , the plant $\left(\mathrm{EC}_{50}=0.027 \mathrm{mg} / \mathrm{ml}\right)$ had a significantly $(P<0.05)$ high inhibitory effect on $\mathrm{Fe}^{2+}$-induced lipid peroxidation in the testes homogenate. The decrease in the $\mathrm{Fe}^{2+}$-induced lipid peroxidation in the rat testes homogenates in the presence of the extract could be as result of the ability of the extracts to chelate $\mathrm{Fe}^{2+}$ and/or scavenge free radicals produced by the $\mathrm{Fe}^{2+}$-catalyzed production of reactive oxygen species (ROS) in the rat testes.

Antioxidants carry out their protective role on cells either by preventing the production of free radicals or by neutralizing/scavenging free radicals produced in the body or by reducing/chelating the transition metal composition of foods $[27,40]$. In an attempt to explain the main mechanism through which the water extractable phytochemicals 
TABLE 3: $\mathrm{Fe}^{2+}$-chelating ability and Ferric reducing antioxidant properties (FRAP) of aqueous extract of Cissus populnea (stem bark).

\begin{tabular}{lc}
\hline $\mathrm{Fe}^{2+}$ chelating ability (\%) & FRAP (\%) \\
\hline $93.25 \pm 0.81$ & $11.52 \pm 0.04$ \\
\hline
\end{tabular}

Values represent mean \pm standard deviation, number of samples $n=3$.

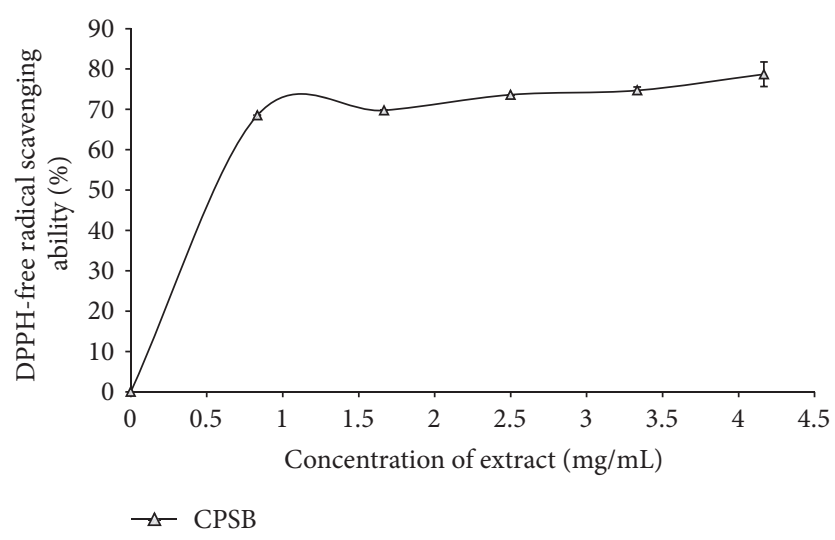

FIGURE 2: DPPH radical scavenging ability of aqueous extract of stem bark of Cissus populnea.

in the plant extract protect testes tissue against $\mathrm{Fe}^{2+}$-induced lipid peroxidation, the DPPH radical scavenging and $\mathrm{Fe}^{2+}$ chelating abilities were assessed. The prevention of the chain initiation step by scavenging various reactive species such as free radicals is considered to be an important antioxidant mode of action [41]. DPPH is a free radical donor that accepts an electron or hydrogen to become a stable diamagnetic molecule [42]. The tendencies of electron or hydrogen donation are critical factors in characterizing antioxidant activity that involves free radical scavenging [43]. Foods of plant origin usually contain natural antioxidants that can scavenge free radicals [6]. These antioxidants are polyphenolic compounds which have protective effect against diseases [6] and can be found in all plants and in all parts of the plants (tree bark, stalks, leaves, fruits, roots, flowers, pods, and seeds) [6]. The DPPH radical scavenging ability of the aqueous extract from C. populnea as represented in Figure 2 revealed that the extract scavenged DPPH radicals in a dosedependent pattern $(0-3.33 \mathrm{mg} / \mathrm{mL})$.

The plant extracts also chelate $\mathrm{Fe}^{2+}$ (Table 3). This result, however, is in agreement with the $\mathrm{Fe}^{2+}$-induced lipid peroxidation (Figure 1), phenolic content (Table 1), and antioxidant activity of the extracts, suggesting that Fe chelation may be one of the possible mechanisms through which antioxidant phytochemicals from stem bark of C. populnea prevent lipid peroxidation in tissue by forming a complex with $\mathrm{Fe}$, thus preventing the initiation of lipid peroxidation.

Furthermore, the reducing power of the extractable phytochemicals from Cissus populnea (stem bark) expressed as ascorbic acid equivalent (AAE) is presented in Table 3. The reducing power as typified by the ability of the plant extracts to reduce $\mathrm{Fe}^{3+}$ to $\mathrm{Fe}^{2+}$ is a potent antioxidation defense mechanism, and two mechanisms available to affect this reducing power is by electron transfer and hydrogen atom transfer [28]. Allhorn et al. [44] reported that the reducing property can be a novel antioxidant defense mechanism, possibly through the ability of the antioxidant compound to reduce transition metals. Therefore, the higher reducing ability of Cissus populnea extract may have contributed to the higher protective effect observed.

Likewise, the incubation of rat's testes tissue homogenates in presence of sodium nitroprusside also caused a significant increase $(P<0.05)$ in the rat's testes malondialdehyde (MDA) content as shown in Figure 1(b); however, the extract inhibited MDA production content in the tissue in a dosedependent $(0-0.63 \mathrm{mg} / \mathrm{ml})$. However, judging by the $\mathrm{EC}_{50}$ value in Table 2, the aqueous extract of $C$. populnea had a high inhibitory effect on sodium nitroprusside-induced lipid peroxidation in rat testes. The protective properties of the plant extract against sodium nitroprusside-induced lipid peroxidation in the testes could be because of the ability of the antioxidant phytochemicals present in the aqueous extract to quench-scavenge the nitrous radical and Fe produced from the decomposition of sodium nitroprusside.

\section{Conclusion}

The aqueous extract of stem bark of C. populnea was able to protect the testes homogenate from both $\mathrm{Fe}^{2+}$ - and SNPinduced lipid peroxidation in vitro. A part of the mechanisms through which the water extractable phytochemicals in the plant protect the testes from oxidative stress may be through their phenolic content and antioxidant activity; DPPH-scavenging ability, $\mathrm{Fe}^{2+}$-chelating and -reducing power. Therefore, oxidatively stress testes could be potentially managed/prevented by this plant.

\section{Conflict of Interests}

No competing financial interests exist.

\section{References}

[1] B. Halliwell and J. M. C. Gutteridge, Free Radicals in Biology and Medicine, Clarendon, Oxford, UK, 1993.

[2] R. S. Britton, K. L. Leicester, and B. R. Bacon, "Iron toxicity and chelation therapy," International Journal of Hematology, vol. 76, no. 3, pp. 219-228, 2002.

[3] Y. Sugiyama, S. Kawakishi, and T. Osawa, "Involvement of the $\beta$-diketone moiety in the antioxidative mechanism of tetrahydrocurcumin," Biochemical Pharmacology, vol. 52, no. 4, pp. 519-525, 1996.

[4] M. Naito, T. Hayashi, and A. Iguchi, "New approaches to the prevention of atherosclerosis," Drugs, vol. 50, no. 3, pp. 440-453, 1995.

[5] M. Naito, M. Kuzuya, and A. Iguchi, "Mechanisms of endothelial cell injury induced by oxidatively modified LDL," Journal of Japan Atherosclerosis Society, vol. 22, pp. 257-262, 1994.

[6] T. Osawa, S. Yoshida, K. Yamashida, and H. Ochi, "Protective role of dietary antioxidants in oxidative stress," in Oxidative 
Stress and Aging, R. G. Cutler, L. Packer, J. Bertram, and A. Mori, Eds., pp. 367-377, Birkhauser, Basel, Switzerland, 1995.

[7] W. M. Koné, K. Kamanzi Atindehou, C. Terreaux, K. Hostettmann, D. Traoré, and M. Dosso, "Traditional medicine in North Côte-d'Ivoire: screening of 50 medicinal plants for antibacterial activity," Journal of Ethnopharmacology, vol. 93, no. 1, pp. 43-49, 2004.

[8] S. E. Atawodi, D. A. Ameh, S. Ibrahim et al., "Indigenous knowledge system for treatment of trypanosomiasis in Kaduna State of Nigeria," Journal of Ethnopharmacology, vol. 79, no. 2, pp. 279-282, 2002.

[9] J. O. Moody, O. O. Ojo, O. O. Omotade, A. A. Adeyemo, P. E. Olumese, and O. O. Ogundipe, "Anti-sickling potential of a Nigerian herbal formula (ajawaron HF) and the major plant component (Cissus populnea L. CPK)," Phytotherapy Research, vol. 17, no. 10, pp. 1173-1176, 2003.

[10] S. R. Belmain, P. Golo, H. F. Andan, H. Atarigiya, F. A. Chare, and P. Carr, "Toxicity and repellency of ethnobotanicals used in Ghana as post harvest protectants," Phytoparasitic, vol. 28, no. 1, pp. 87-90, 2000, Abstracts of Presentations on Selected Topics at the 14th International Plant Protection Congress (IPPC).

[11] A. B. Ojekale, O. A. Lawal, A. K. Lasisi, and T. I. Adeleke, "Phytochemisty and spermatogenic potentials of aqueous extract of Cissus populnea (Guill. and Per) stem bark," TheScientificWorldJournal, vol. 6, pp. 2140-2146, 2006.

[12] Joint Reports, 2004.

[13] G. Oboh, R. L. Puntel, and J. B. T. Rocha, "Hot pepper (Capsicum annuum, Tepin and Capsicum chinese, Habanero) prevents $\mathrm{Fe}^{2+}$-induced lipid peroxidation in brain-in vitro," Food Chemistry, vol. 102, no. 1, pp. 178-185, 2007.

[14] V. L. Singleton, R. Orthofer, and R. M. Lamuela-Raventos, "Analysis of total phenols and other oxidation substrates and antioxidants by means of Folin-Ciocalteu Reagent," in Oxidants and Antioxidants. Methods in Enzymology, Part A, vol. 299, pp. 152-178, Academic Press, San Diego, Calif, USA, 1999.

[15] A. Meda, C. E. Lamien, M. Romito, J. Millogo, and O. G. Nacoulma, "Determination of the total phenolic, flavonoid and proline contents in Burkina Fasan honey, as well as their radical scavenging activity," Food Chemistry, vol. 91, no. 3, pp. 571-577, 2005.

[16] M. Benderitter, V. Maupoil, C. Vergely, F. Dalloz, F. Briot, and L. Rochette, "Studies by electron paramagnetic resonance of the importance of iron in the hydroxyl scavenging properties of ascorbic acid in plasma: effects of iron chelators," Fundamental and Clinical Pharmacology, vol. 12, no. 5, pp. 510-516, 1998.

[17] H. Ohkawa, N. Ohishi, and K. Yagi, "Assay for lipid peroxides in animal tissues by thiobarbituric acid reaction," Analytical Biochemistry, vol. 95, no. 2, pp. 351-358, 1979.

[18] M. A. Gyamfi, M. Yonamine, and Y. Aniya, "Free-radical scavenging action of medicinal herbs from GhanaThonningia sanguinea on experimentally-induced liver injuries," General Pharmacology, vol. 32, no. 6, pp. 661-667, 1999.

[19] G. Minotti and S. D. Aust, "An investigation into the mechanism of citrate- $\mathrm{Fe}^{2+}$-dependent lipid peroxidation," Free Radical Biology and Medicine, vol. 3, no. 6, pp. 379-387, 1987.

[20] R. L. Puntel, C. W. Nogueira, and J. B. T. Rocha, "Krebs cycle intermediates modulate thiobarbituric acid reactive species (TBARS) production in rat brain in vitro," Neurochemical Research, vol. 30, no. 2, pp. 225-235, 2005.

[21] M. Oyaizu, "Studies on products of browning reaction: antioxidative activity of products of browning reaction prepared from glucosamine," Japanese Journal of Nutrition, vol. 44, pp. 307-315, 1986.

[22] J. H. Zar, ,Biostatistical Analysis, Prentice-Hall, Upper Saddle River, NJ, USA, 1984.

[23] Y. F. Chu, J. Sun, X. Wu, and R. H. Liu, "Antioxidant and antiproliferative activities of common vegetables," Journal of Agricultural and Food Chemistry, vol. 50, no. 23, pp. 6910-6916, 2002.

[24] G. Oboh and J. B. T. Rocha, "Water extractable phytochemicals from Capsicum pubescens (tree pepper) inhibit lipid peroxidation induced by different pro-oxidant agents in brain: in vitro," European Food Research and Technology, vol. 226, no. 4, pp. 707713, 2008.

[25] G. Oboh, "Effect of blanching on the antioxidant properties of some tropical green leafy vegetables," LWT_Food Science and Technology, vol. 38, no. 5, pp. 513-517, 2005.

[26] G. Oboh and A. A. Akindahunsi, "Change in the ascorbic acid, total phenol and antioxidant activity of sun-dried commonly consumed green leafy vegetables in Nigeria," Nutrition and Health, vol. 18, no. 1, pp. 29-36, 2004.

[27] D. Amic, D. Davidovic-Amic, D. Beslo, and N. Trinajstic, "Structure-radical scavenging activity relationship of flavonoids," Croatica Chemica Acta, vol. 76, pp. 55-61, 2003.

[28] G. Oboh, "Polyphenol extracts from Hyptis suaveolens leaves inhibit $\mathrm{Fe}^{2+}$-induced lipid peroxidation in brain," International Journal of Biomedical and Pharmaceutical Sciences, vol. 2, pp. 41-46, 2008.

[29] A. Marín, F. Ferreres, F. A. Tomás-Barberán, and M. I. Gil, "Characterization and quantitation of antioxidant constituents of sweet pepper (Capsicum annuum L.)," Journal of Agricultural and Food Chemistry, vol. 52, no. 12, pp. 3861-3869, 2004.

[30] G. Oboh, R. L. Puntel, and J. B. T. Rocha, "Hot pepper (Capsicum annuum, Tepin and Capsicum chinese, Habanero) prevents $\mathrm{Fe}^{2+}$-induced lipid peroxidation in brain-in vitro," Food Chemistry, vol. 102, no. 1, pp. 178-185, 2007.

[31] M. Materska and I. Perucka, "Antioxidant activity of the main phenolic compounds isolated from hot pepper fruit (Capsicum annuum L.)," Journal of Agricultural and Food Chemistry, vol. 53, no. 5, pp. 1750-1756, 2005.

[32] E. Kronhausen, P. Kronhausen, B. Harry, and M. D. Demopoulos, Formula for Life, William Morrow, New York, NY, USA, 1989.

[33] L. Calucci, C. Pinzino, M. Zandomeneghi et al., "Effects of $\gamma$ irradiation on the free radical and antioxidant contents in nine aromatic herbs and spices," Journal of Agricultural and Food Chemistry, vol. 51, no. 4, pp. 927-934, 2003.

[34] G. Oboh, "Antioxidant properties of some commonly consumed and underutilized tropical legumes," European Food Research and Technology, vol. 224, no. 1, pp. 61-65, 2006.

[35] R. J. Aitken, D. Harkiss, and D. W. Buckingham, "Analysis of lipid peroxidation mechanisms in human spermatozoa," Molecular Reproduction and Development, vol. 35, no. 3, pp. 302-315, 1993.

[36] J. Aitken and H. Fisher, "Reactive oxygen species generation and human spermatozoa: the balance of benefit and risk," BioEssays, vol. 16, no. 4, pp. 259-267, 1994.

[37] K. Narayana, "An aminoglycoside antibiotic gentamycin induces oxidative stress, reduces antioxidant reserve and impairs spermatogenesis in rats," Journal of Toxicological Sciences, vol. 33, no. 1, pp. 85-96, 2008. 
[38] M. P. Zago, S. V. Verstraeten, and P. I. Oteiza, "Zinc in the prevention of $\mathrm{Fe}^{2+}$-initiated lipid and protein oxidation," Biological Research, vol. 33, no. 2, pp. 143-150, 2000.

[39] Y. Minamiyama, S. Takemura, S. Kodai et al., "Iron restriction improves type 2 diabetes mellitus in Otsuka LongEvans Tokushima fatty rats," American Journal of PhysiologyEndocrinology and Metabolism, vol. 298, no. 6, pp. E1140-E1149, 2010.

[40] M. Alía, C. Horcajo, L. Bravo, and L. Goya, "Effect of grape antioxidant dietary fiber on the total antioxidant capacity and the activity of liver antioxidant enzymes in rats," Nutrition Research, vol. 23, no. 9, pp. 1251-1267, 2003.

[41] K. Dastmalchi, H. J. Damien Dorman, M. Kosar Muberra, and R. Hiltunen, "Chemical composition and in vitro antioxidant evaluation of a water-soluble Moldavian balm (Dracocephalum moldavica L.) extract," LWT_Food Science and Technology, vol. 40, no. 2, pp. 239-248, 2007.

[42] J. Y. Je, P. J. Park, E. K. Kim, and C. B. Ahn, "Antioxidant and angiotensin I converting enzyme inhibitory activity of Bambusae caulis in Liquamen," Food Chemistry, vol. 113, no. 4, pp. 932-935, 2009.

[43] C. Hu, Y. Zhang, and D. D. Kitts, "Evaluation of antioxidant and prooxidant activities of bamboo Phyllostachys nigra var. Henonis leaf extract in vitro," Journal of Agricultural and Food Chemistry, vol. 48, no. 8, pp. 3170-3176, 2000.

[44] M. Allhorn, A. Klapyta, and B. Åkerström, "Redox properties of the lipocalin $\alpha 1$-microglobulin: reduction of cytochrome c, hemoglobin, and free iron," Free Radical Biology and Medicine, vol. 38 , no. 5, pp. 557-567, 2005. 

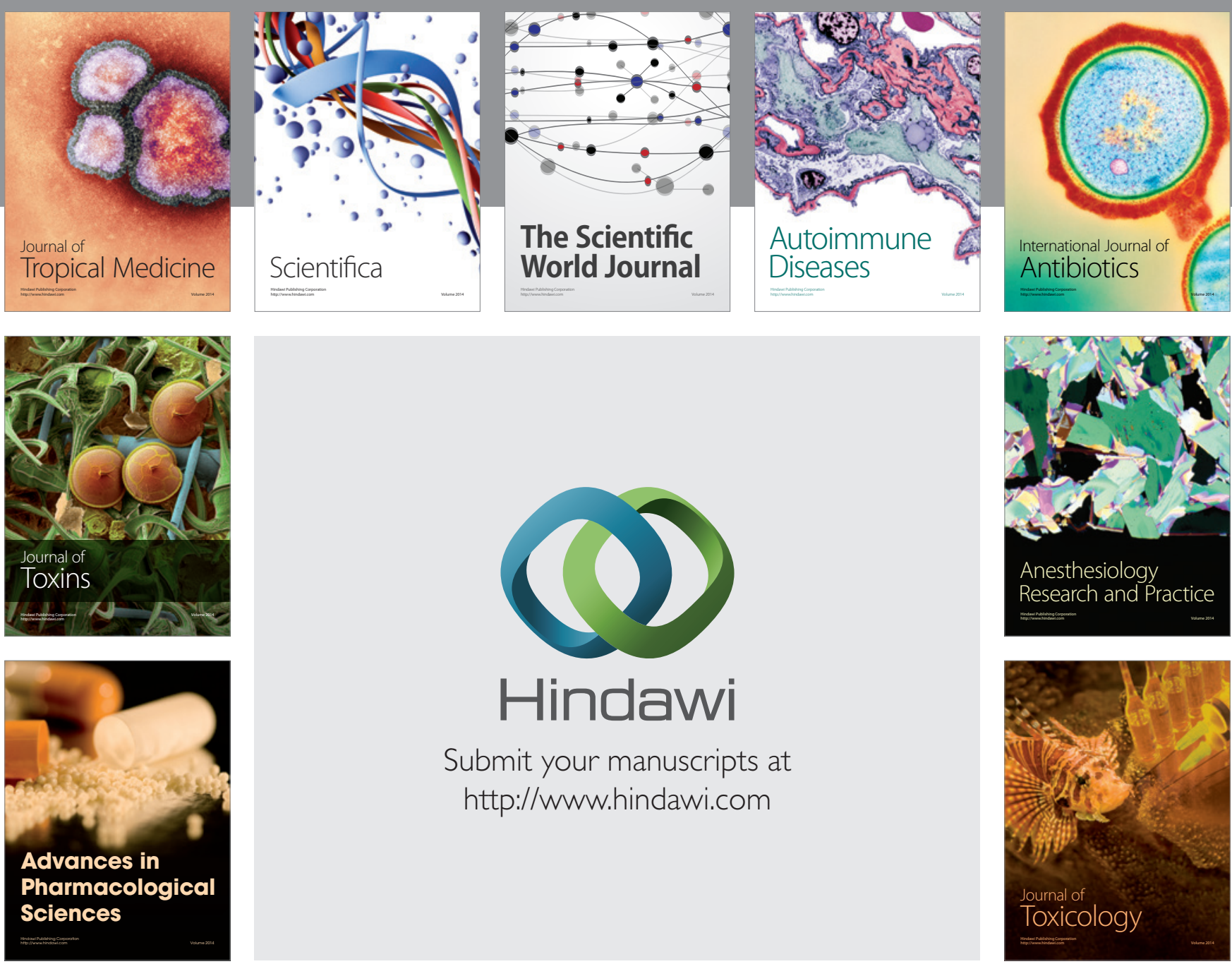

\section{Hindawi}

Submit your manuscripts at

http://www.hindawi.com
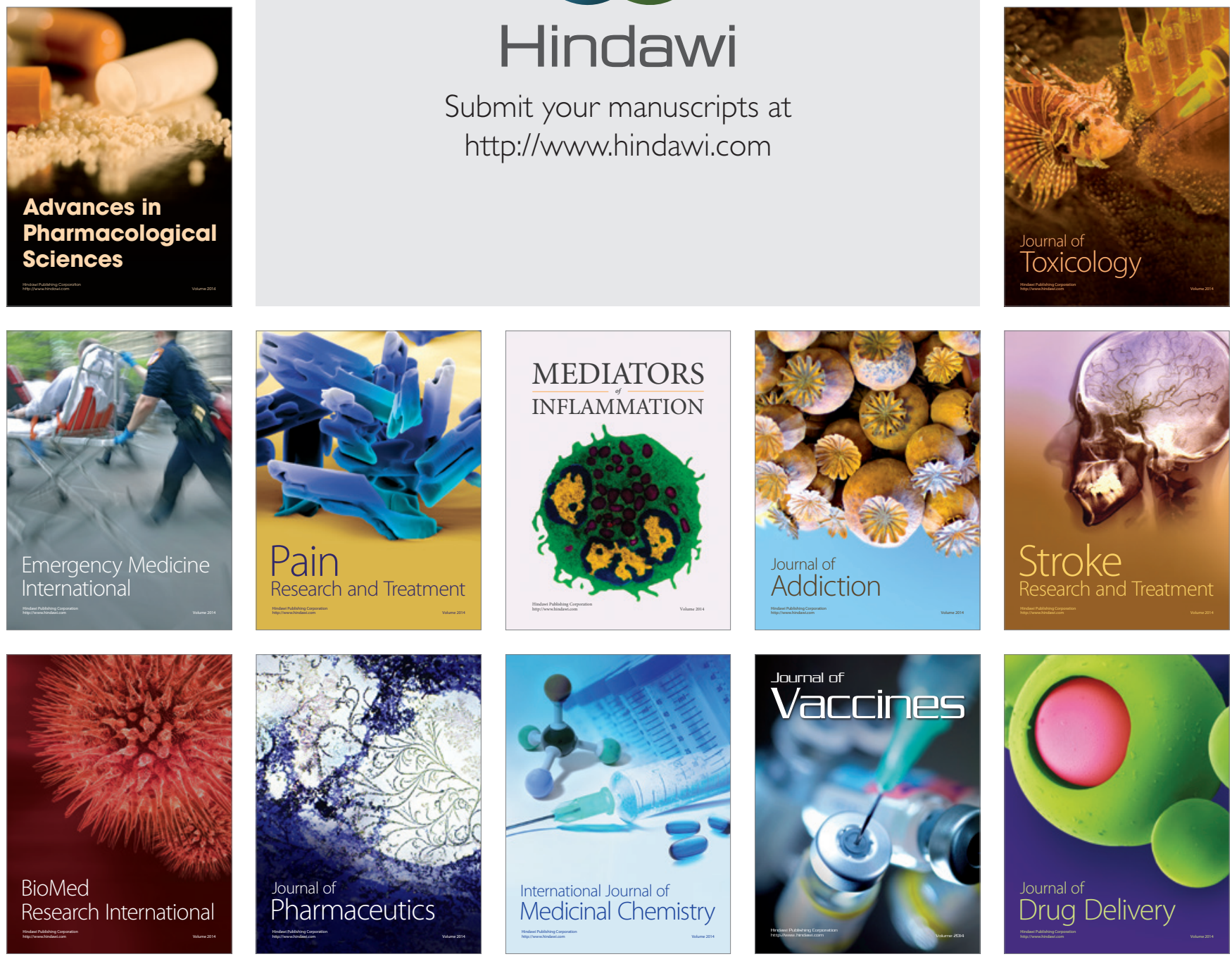